\title{
Aplikasi Penganalisis Kelayakan Ekonomi dalam Pengolahan Mineral Batubara dan Peningkatan Nilai Tambah Maupun Investasi yang Layak Secara Komersial di Indonesia
}

\author{
Frances Roi Seston Tampubolon *)1), Abu Sopian²) \\ ${ }^{1)}$ Program Studi Sistem Manajemen Informatika, Universitas Mohammad Husni Thamrin \\ ${ }^{2}$ Program Studi Teknik Informatika, Universitas Mohammad Husni Thamrin \\ ${ }^{*}$ Correspondence author: franjkt@ hotmail.com, DKI Jakarta, Indonesia
}

\begin{abstract}
Abstrak
Persyaratan wajib yang diperlukan mengenai pemrosesan Mineral dan Batubara adalah untuk meningkatkan nilai tambah mineral yang akan diekspor dan untuk melestarikan pasokan mineral dalam negeri. Beberapa perusahaan pertambangan harus mempertimbangkan investasi tambahan dalam fasilitas peleburan dan pemurnian. Pertanyaan selanjutnya adalah apakah larangan ekspor akan berdampak besar pada bisnis pertambangan dan apakah investasi ini layak secara komersial. Sehubungan dengan Peraturan Menteri Energi dan Sumber Daya Mineral No. 7 tahun 2012 karena tidak adanya rencana komprehensif pemegang IUP mineral untuk melaksanakan Undang-Undang dan khususnya dalam pengembangan fasilitas pengolahan dan pemurnian atau juga dalam bentuk mineral memproses dan memperbaiki kerjasama di dalam negeri. Selama tiga tahun terakhir setelah UU tersebut diterbitkan, diindikasikan bahwa telah terjadi peningkatan ekspor bijih mineral dalam jumlah besar seperti ekspor bijih nikel meningkat sebesar 750\%, bijih besi meningkat $700 \%$ dan bijih bauksit meningkat 500\% . Untuk mengontrol ekspor bijih mineral (KESDM, 2011) perlu untuk membuat ketersediaan bahan baku untuk memproses dan memurnikan mineral di negara tersebut dan mencegah dampak negatif terhadap lingkungan. Dalam penelitian ini saya akan melakukan penelitian khusus dalam pengolahan bahan baku mineral. Hasil penelitian sebelumnya dijadikan perbandingan dalam penelitian ini tetapi tidak dapat dipisahkan dari tema topik yaitu peningkatan nilai tambah dan investasi khusus dalam pengolahan bahan baku mineral (kasus batubara dan minyak kelapa sawit). Kegiatan penambangan selama 50 tahun konsep dasar secara umum relatif tidak berubah apa perubahan adalah skala kegiatan. Skala penambangan juga akan semakin besar seiring dengan mekanisasi peralatan penambangan. Pemrosesan ekstraksi bijih kadar rendah menjadi lebih ekonomis membutuhkan pengembangan teknologi pemrosesan yang semakin tinggi juga. Ini juga akan menyebabkan lapisan bumi yang lebih luas dan lebih dalam digali. Kegiatan penambangan yang disebutkan di atas akan secara langsung atau tidak langsung memiliki dampak besar juga dan dampaknya terhadap lingkungan harus diantisipasi. Menurut Bank Dunia, 1998, kegiatan penambangan memiliki pengaruh yang cukup luas dalam kegiatan mulai dari penggalian ke departemen pemrosesan. Pengaruh yang dapat ditimbulkan adalah selain dampak lingkungan yang juga memiliki pengaruh terhadap dampak sosial. Sebelum memulai kegiatan, biaya lingkungan, sosial dan kesehatan harus dipertimbangkan dan opsi alternatif untuk kegiatan yang akan dipilih. Juga penting untuk mengendalikan, mengelola, dan memantau langkah-langkah yang harus memiliki hubungan dalam perencanaan dan implementasi untuk upaya penutupan tambang.
\end{abstract}

Kata Kunci: Nilai Tambah, Pemrosesan, Pengeluaran, Tenaga Kerja

\begin{abstract}
Mandatory requirements needed regarding processing of Minerals are to increase the added value of the minerals to be exported and to conserve domestic mineral supplies. Some mining companies should consider additional investment in smelting and refining facilities. The next question is whether the export ban will have a large impact on the mining business and are these investments commercially viable. In connection with Regulation of the Minister of Energy and Mineral Resources No. 7 of 2012 due to the absence of a comprehensive plan of mineral IUP holders to implement the Act and specifically in the development of processing and refining facilities or also in the form of mineral processing and refining cooperation in the country. For the last three years after the Act was issued, it was indicated that there had been an increase in mineral ore exports in large quantities such as nickel ore exports increasing by $750 \%$, iron ore increasing by $700 \%$ and bauxite ore increasing by 500\%. To control the export of mineral ores (MEMR, 2011) it is necessary to make availability of raw materials for processing and refining minerals in the country and prevent negative impacts on the environment. In this research I will conduct special research in the
\end{abstract}


processing of raw mineral materials. The results of the previous studies were made into a comparison in this study but are inseparable from the theme of the topic namely increasing value added and special investment in processing raw mineral materials (the case of coal and palm oil). Mining activities for 50 years the basic concept in general is relatively unchanged what changes is the scale of the activity. The scale of mining will also be greater in line with the mechanization of mining equipment. The processing of low grade ore extraction into more economic value requires the development of increasingly higher processing technologies as well. This will also cause wider and deeper layers of the earth to be dug up. The mining activities mentioned above will directly or indirectly have a large impact as well and their impacts on the environment must be anticipated. According to the World Bank, 1998, mining activities had quite extensive influence in activities ranging from excavation to the processing department. The influence that can be caused is in addition to environmental impacts that also have an influence on social impacts. Before starting activities, environmental, social and health costs must be considered and alternative options for activities to be chosen. It is also necessary to control, manage and monitor the steps must have a relationship in the planning and implementation for the mine closure effort.

Keywords: Value Added, Processing, Expenditures, Labor

\section{PENDAHULUAN}

Untuk mengolah bahan mineral mentah dengan peningkatan nilai tambah sangat diperlukan karena kebutuhan juga semakin meningkat. Sumber daya alam tak terbarukan (mineral) yang sering kita gunakan berasal dari minyak mentah dan bahan mineral mentah seperti batu bara, timah, nikel dan lainnya. Oleh karena itu, perlu untuk meningkatkan nilai tambah bahan mineral mentah atau dengan melakukan diversifikasi pengolahan bahan mineral (untuk kasus di Sumatera) dengan teknologi nilai tambah ditambahkan (Kudełko, Wanielista, \& Wirth, 2013).

Penelitian dilakukan khusus dalam pengolahan bahan baku mineral. Hasil penelitian sebelumnya dijadikan perbandingan dalam penelitian ini tetapi tidak dapat dipisahkan dari tema topik, yaitu peningkatan nilai tambah dan investasi khusus dalam pengolahan bahan mineral mentah. Untuk melakukan kegiatan meningkatkan nilai tambah, diperlukan pengembangan teknologi, terutama pengembangan pengolahan mineral (misalnya smelter). Untuk mengembangkan metode pengolahan mineral, diperlukan analisis untuk nilai tambah dan investasi yang dimungkinkan di dalamnya. Selanjutnya, dalam penelitian akan dianalisis kemungkinan produksi yang akan diperoleh di dalamnya (Leeson, Mac Dowell, Shah, Petit, \& Fennell, 2017). Produksi yang akan dikaji dalam penelitian ini akan seperti model di bawah ini: 


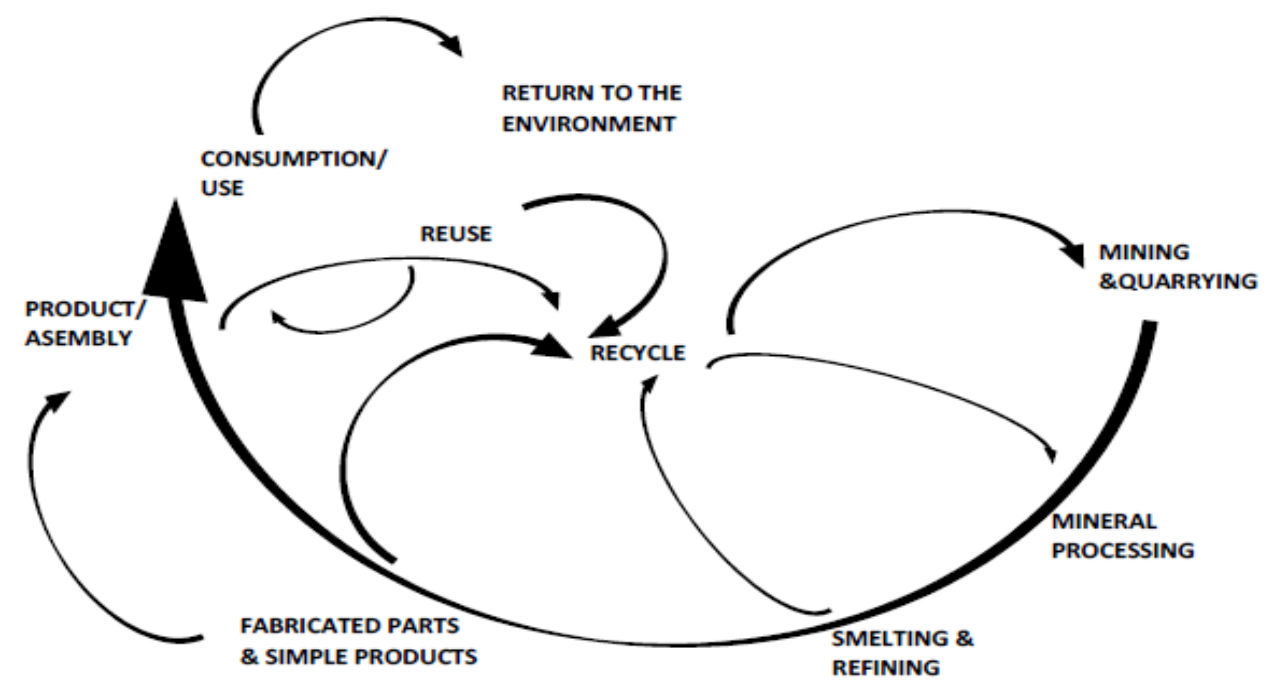

Gambar 1. Siklus Proses Dalam Pengolahan Mineral

Data yang memungkinkan untuk pemrosesan analitis menjadi sangat penting, terutama dalam produksi pengolahan mineral mentah (dalam hal ini batubara). Beberapa perusahaan mitra telah berpartisipasi untuk melakukan konversi dan meningkatkan kegiatan bernilai tambah. Sangat diharapkan keterlibatan sektor swasta (perusahaan) yang mungkin ingin melakukan kontribusi pada penelitian ini selain kegiatan CSR (Corporate Social Responsibility). (Wirth, Kulczycka, Hausner, \& Koński, 2016)

Dalam jangka pendek, kebijakan terbaru di sektor mineral telah menyebabkan polemik. Banyak orang menganggap kebijakan ini merugikan ekonomi nasional. (Heinrich, Koschinsky, Markus, \& Singh, 2019) Namun, dalam jangka panjang, kebijakan ini adalah bentuk terbaik untuk meningkatkan nilai tambah dan neraca perdagangan terutama jika ditambah dengan inovasi teknologi dan peningkatan infrastruktur utama.

Untuk berinvestasi menurut Sugiharto (2008) setiap perusahaan perlu memiliki industri pengolahan agar investasinya dapat tumbuh sesuai dengan tujuan perusahaan, yaitu untuk memperoleh laba sebesar mungkin. Oleh karena itu, perlu dilakukan analisis keuangan untuk menentukan kelayakan ekonomi sehingga investasi dilakukan sesuai dengan visi dan misi perusahaan. Analisis keuangan yang dilakukan adalah memperkirakan arus kas proyek setiap tahun selama umur ekonomi proyek.

Tujuan dari penelitian ini adalah menganalisis kelayakan ekonomi dari pengolahan mineral mentah dan meningkatkan nilai tambah dan investasi. Selain analisis kelayakan ekonomi akan dihitung biaya dan manfaat yang diharapkan dengan membandingkan pengeluaran dan pendapatan seperti ketersediaan dana, biaya modal, kemampuan proyek untuk meningkatkan produksi dalam waktu yang ditentukan. Batasan dalam penelitian ini mulai dari pengolahan mineral, biaya pemrosesan dan hasil keluaran yang dihasilkan dalam 
bentuk penggunaan batubara untuk domestik, kemudian dalam penelitian ini sebagai konsumen adalah PLN (pembangkit listrik negara) dan untuk penjualan (ekspor) ke di luar negeri. Untuk penelitian yang termasuk di luar penelitian ini, akan dijelaskan bahwa variabel yang tidak disebutkan dalam persentase dijelaskan bahwa pengaruh akan ada di luar model.

Penambangan adalah bagian atau seluruh tahapan kegiatan dalam penelitian, pengolahan dan eksploitasi mineral atau batubara yang meliputi penyelidikan umum, eksplorasi, studi kelayakan konstruksi, penambangan, pemrosesan dan pemurnian, transportasi dan penjualan, dan pada tahap akhir biasanya pasca-aksi. Pasca penambangan merupakan kegiatan yang sangat diharapkan oleh pemerintah sehingga kelanjutan kegiatan penambangan dapat berdampak pada peningkatan lingkungan di sekitar tambang baik lingkungan sosial maupun lingkungan alam. Bisnis pertambangan pada dasarnya adalah bisnis penggalian mineral dari bumi (Smoliński, 2019)

Sifat sumber daya mineral adalah sumber yang tidak terbarukan, oleh karena itu penggunaan dan pemanfaatannya harus mampu menjaga keseimbangan dan untuk keselamatan dan pelestarian lingkungan (Majer, 2013).

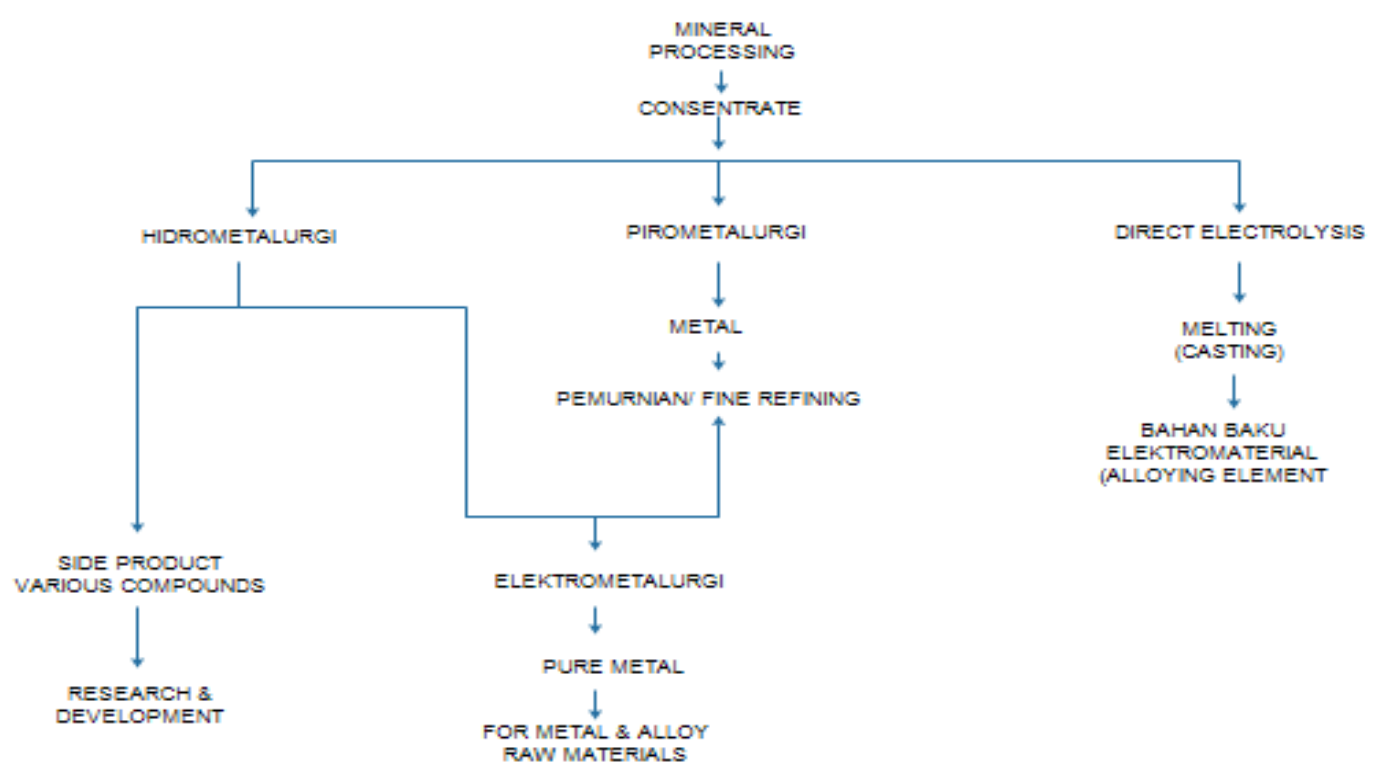

Gambar 2. Jalur Utama Mengolah Bahan Mineral (Edi A Basuki et al, 2007)

Mineral olahan dibuat sesuai dengan ukuran sebelum dihancurkan di jaw crusher dan cone crusher seperti yang diilustrasikan dalam Gambar 3 di bawah ini. Ukuran dimulai dari ukuran $500 \mathrm{~mm}$ yang dimasukkan ke pengumpan grizzly. Selanjutnya, umpan telah dibuat dalam ukuran yang sesuai untuk dimasukkan di bagian ball mill. (Wijaya, Hartono, Widodo, \& B, 2015) Di dalam ball mill akan digiling untuk mencapai ukuran yang sesuai 
di bagian classifier, setelah melewati classifier, ukuran yang diinginkan akan mencapai $<100$ mikron (Febrianto, Nursanto, \& Poetranto, 2016).

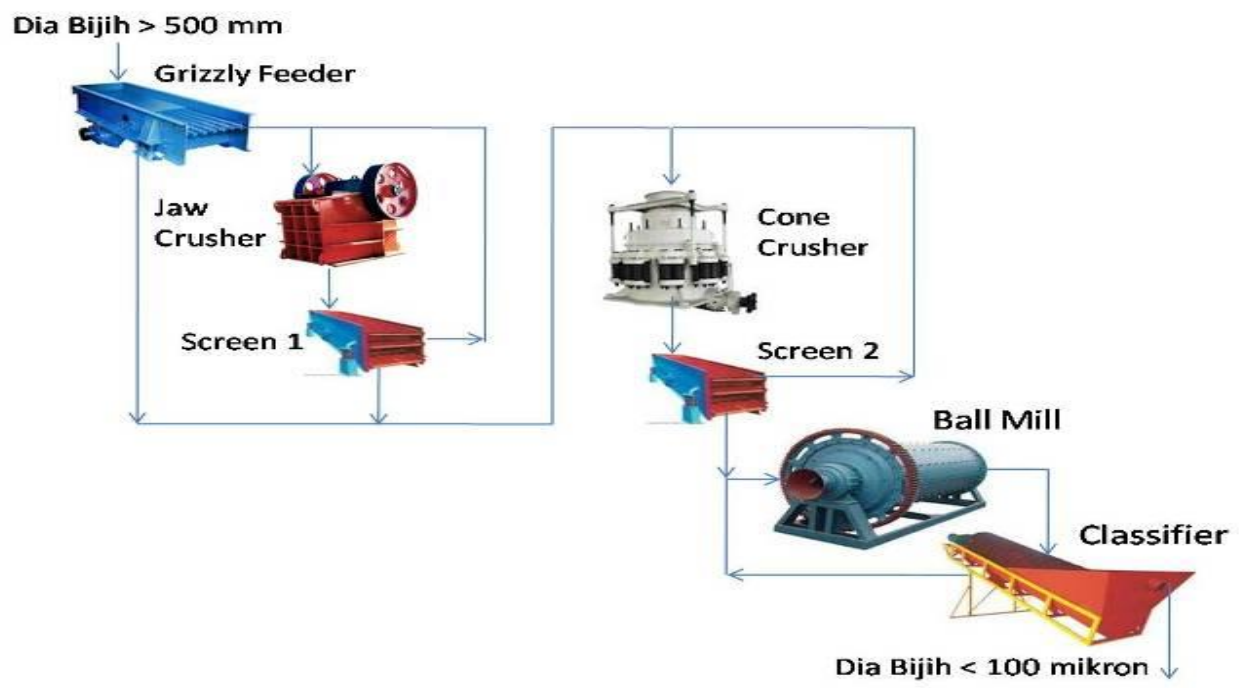

Gambar 3. Proses pengurangan ukuran mineral (comminution)

Tujuan yang jelas memberikan dasar untuk merancang metode penelitian dan manajemen yang tepat. Tujuan dari penelitian ini adalah sebagai berikut:

a. Untuk menganalisis pengaruh kegiatan penambangan dalam pengolahan mineral mentah pada peningkatan nilai tambah dari hasil yang digunakan oleh konsumen domestik (DOM) dan ekspor (EKS)

b. Untuk melihat layak tidaknya pengolahan. Dalam penelitian ini termasuk sebagai pengolahan, yaitu: jumlah bahan baku (JBB), jumlah produksi (JP), jumlah tenaga kerja produksi (TK), jumlah of hour meter (HM).

c. Untuk menganalisis hubungan antar variabel dalam penelitian. Variabel biaya pengeluaran, yaitu: alat berat (AB), jumlah bensin $(B E N)$ dan waktu perawatan (MAIN).

Hasil penelitian ini memiliki target keluaran baik sebagai referensi atau kontribusi untuk penelitian lebih lanjut dalam berbagai disiplin ilmu dalam bentuk publikasi jurnal nasional tidak terakreditasi, lokakarya atau seminar tentang pengolahan mineral.

Dari penelitian ini manfaat penelitian yang akan diperoleh sebagai berikut:

a. Memerikan masukan kepada pengusaha untuk dapat mengelola mineral seperti batubara sehingga penggunaan bahan baku atau tenaga kerja dapat lebih efektif dan efisien.

b. Mencapai target untuk penggunaan batu bara untuk domestik sehingga pengolahan mineral akan menjadi nilai tambah. 
c. Meningkatkan jumlah penjualan ekspor yang lebih bernilai tambah dan tidak hanya menjual mineral mentah, tetapi juga bisa menjual mineral bernilai tambah.

\section{METODE}

Penelitian ini dilakukan di area penambangan jasa penambangan energi dan mineral di Palembang pada 10-12 Juni 2019. Variabel penelitian yang terkandung dalam penelitian ini menggunakan metode SEM PLS (Structural Equation Modeling). Metode dan desain akan didasarkan pada data dan beberapa referensi dari BPS, Kementerian Energi dan Sumber Daya Mineral, LIPI, dan Kementerian Direktorat Jenderal Mineral dan Batubara Bandung. Data dikumpulkan dari data primer dan data sekunder untuk mendapatkan data variabel yang dimasukkan dalam model menggunakan metode SEM PLS (Structural Equation Modeling).

Penelitian ini menggunakan metode SEM PLS yang digambarkan pada gambar 4.

Dengan model yang telah dijelaskan di gambar 4, model tersebut akan dianalisis dengan metode SEM PLS (Part Least Square). Mengingat variabel yang telah dijelaskan dengan hubungan antara variabel dan indikator yang mempengaruhinya dan berapa persentase pengaruh variabel dalam model dengan (Studi Kasus Provinsi) untuk periode waktu mingguan dari April hingga Desember 2019.

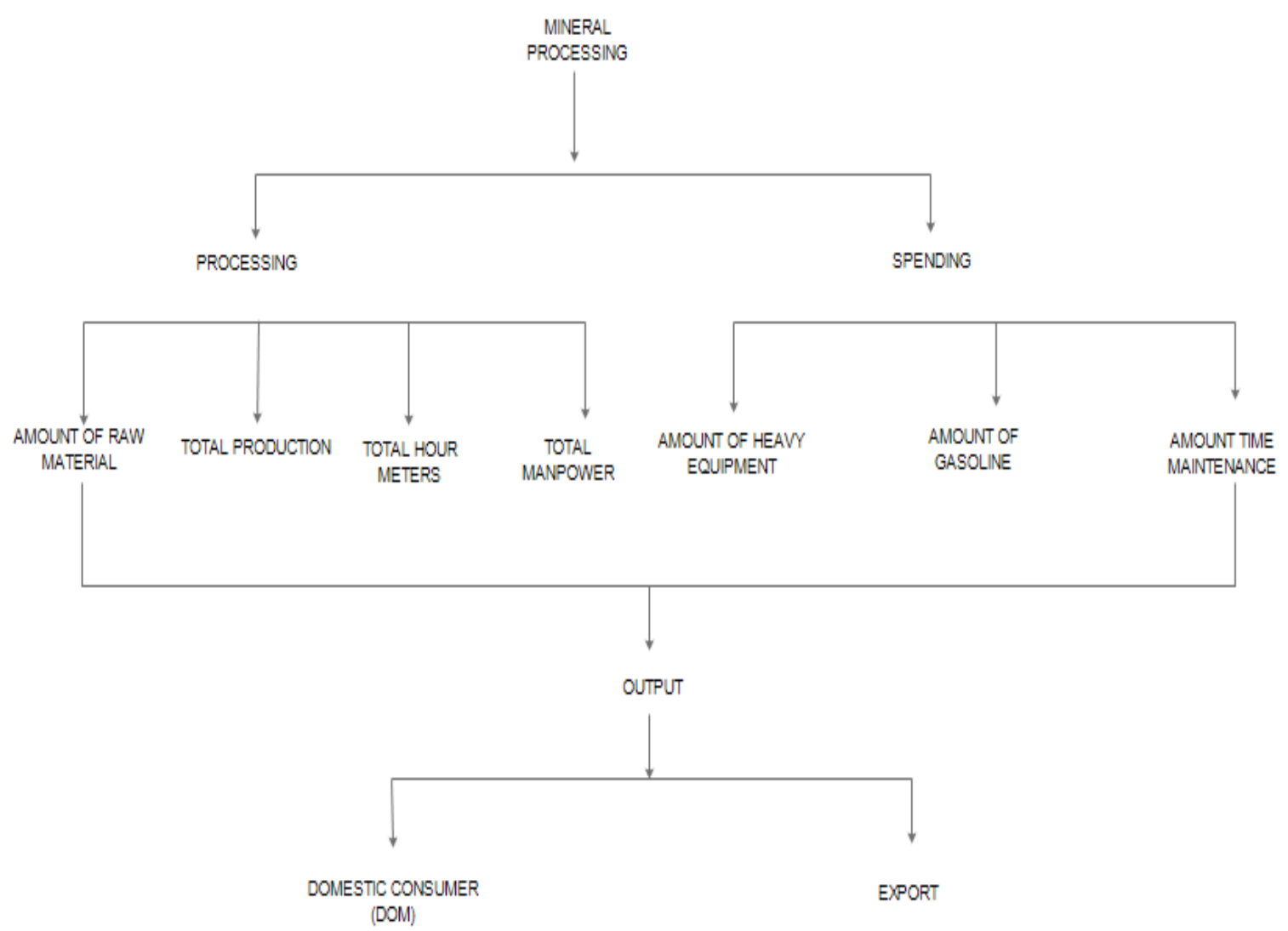

Gambar 4. Model Penelitian 
1. PENGOLAHAN: jumlah bahan baku (JBB), jumlah produksi (JP), jumlah tenaga kerja produksi (TK), jumlah jam meter (HM).

2. BIAYA: alat berat (AB), jumlah bensin (BEN) dan waktu perawatan (MAIN).

3. OUTPUT: tenaga listrik diproduksi / domestik (DOM), pihak lain yang menerima sebagai ekspor (EKS).

Selanjutnya, data yang dikumpulkan akan dianalisis dengan metode SEM, yaitu untuk melihat seberapa besar persentase pengaruh variabel yang digunakan sebagai Pemrosesan, Biaya Pengeluaran dan Output. Analisis ini akan menjadi penelitian dan pengolahan data yang kemudian dapat digunakan untuk menjadi bahan pengetahuan dalam pengolahan minera di Indonesia. Penelitian ini juga akan menjadi dasar untuk kegiatan aksi yang benar-benar perlu dipertimbangkan untuk pengusaha yang ingin terlibat dalam pertambangan di Indonesia.

Persiapan yang dilakukan seperti:

a. Membuat model analisis perencanaan yang akan digunakan.

b. Pembuatan metode yang akan digunakan adalah metode SEM PLS (Part Least Square).

c. Kompilasi data yang berkaitan dengan model yang akan digunakan.

d. Membuat variabel yang menjadi hubungan di antara mereka.

e. Masukkan data yang diperoleh.

f. Analisis hasil metode SEM yang telah dilakukan.

g. Lakukan beberapa tes yang digunakan dalam model SEM PLS.

Data yang diperoleh adalah data kuantitatif dan data kualitatif, yang diperoleh dari pengumpulan data langsung dari kantor dinas pertambangan di provinsi Sumatera Selatan. Selain itu, data tambahan masih tersedia untuk mendukung data di atas, dalam bentuk aktivitas pemrosesan mineral di lokasi, pengelolaan hasil aktivitas dalam pertambangan, respons karyawan terhadap pemrosesan, dan hasil analisis pengukuran kuesioner. Data yang telah dikumpulkan dari situs tambang dapat dibuat dari data seperti yang di bawah ini. (Bochori, Asyik, \& Jhon, 2016) Formulir adalah data yang diperoleh setiap hari atau bulanan dan laporan pemantauan. Formulir akan dibuat untuk setiap kegiatan yang dilakukan di lokasi tambang. Kegiatannya berkisar dari memuat bahan tanah teratas hingga pengiriman ke pelabuhan (pengangkutan) (Hermawan, Kresno, \& Titisariwati, 2016).

Evaluasi model dalam PLS (Partial Least Square) dilakukan dengan mengevaluasi model luar dan model dalam. Evaluasi Model Luar dibagi menjadi dua yaitu model reflektif dan formatif. Dalam model reflektif, model pengukuran adalah untuk menilai validitas dan 
reliabilitas model. Sedangkan model lain adalah model struktural untuk memprediksi hubungan kausalitas antar variabel (Jogiyanto dan Abdillah, 2009).

1. Evaluasi Model Luar reflektif

Model pengukuran digunakan untuk menguji validitas variabel dan reliabilitas indikator. Uji validitas dilakukan untuk mengetahui kemampuan indikator penelitian untuk mengukur apa yang harus diukur. Ada dua jenis tes validitas di SmartPLS:

a. Uji Validitas Konvergen: berkaitan dengan prinsip bahwa pengukuran suatu variabel harus sangat berkorelasi. Validitas konvergen terjadi ketika skor yang diperoleh dari dua instrumen berbeda yang mengukur variabel yang sama memiliki korelasi yang tinggi. Aturan baik yang digunakan untuk validitas konvergen adalah pemuatan luar> 0,5 - 0,7; AVE dan komunitas> 0,5.

b. Uji Validitas Diskriminan; berkaitan dengan prinsip bahwa mengukur variabel yang berbeda tidak boleh berkorelasi dengan tinggi. Validitas diskriminan terjadi ketika dua instrumen berbeda yang mengukur dua variabel yang diprediksi tidak berkorelasi menghasilkan skor yang memang tidak berkorelasi. Uji validitas diskriminan dinilai berdasarkan cross loading > 0,7 dan root AVE> korelasi variabel laten (Jogiyanto dan Abdillah, 2009).

\section{Evaluasi Model Luar Formatif}

- Validitas logis Nomo: hubungan antara indikator dan variabel laten harus telah dibuktikan dalam penelitian sebelumnya.

- Validitas eksternal: R2 besar

- Bobot signifikansi: estimasi bobot model pengukuran formatif harus signifikan

Sedangkan uji reliabilitas digunakan untuk mengukur konsistensi instrumen dalam mengukur suatu konsep. Uji reliabilitas adalah pengukuran yang menunjukkan tingkat pengukuran tanpa bias (bebas kesalahan) dan karena menjamin pengukuran yang konsisten sepanjang waktu dan di berbagai item dalam indikator (Sekaran, 2006).

Dalam PLS tes ini dapat dilakukan dengan menggunakan dua metode, yaitu:

a. Cronbach's alpha: mengukur batas bawah nilai keandalan suatu variabel dan dapat diterima jika nilainya $>0,6$.

b. Reliabilitas komposit: mengukur nilai sebenarnya dari reliabilitas variabel dan dapat diterima jika nilainya $>0,7$

\section{Evaluasi Model Struktural}

Model struktural dalam PLS dievaluasi dengan mengukur koefisien determinasi (R2).

Nilai (R2) digunakan untuk mengukur tingkat variasi dalam perubahan variabel independen ke variabel dependen. Sehingga dapat menggambarkan seberapa besar 
variabel dependen dapat dipengaruhi oleh variabel independen. Semakin tinggi nilainya (R2) semakin baik model prediksi dari model yang diusulkan (Jogiyanto dan Abdillah, 2009).

Evaluasi model keseluruhan dapat diukur menggunakan relevansi prediktif Q-square Rumus Q-square:

$$
Q^{2}=1-\left(1-R_{1}^{2}\right)\left(1-R_{2}^{2}\right)\left(1-R_{p}^{2}\right)
$$

Di mana variabel endogen R-square dalam model. Interpretasi sama dengan koefisien penentuan total dalam analisis jalur (mirip dengan regresi).

\section{Pengujian Hipotesis}

Nilai koefisien jalur menunjukkan signifikansi antara variabel dalam model struktural atau dalam pengujian hipotesis.

a. Hipotesis statistik untuk model luar: lawan

b. Hipotesis statistik untuk model dalam: variabel laten eksogen ke endogen: lawan

c. Hipotesis statistik untuk model dalam: variabel laten endogen menjadi endogen: Lawan

d. Statistik uji: uji-t; p-value (alpha 5\%); penting

e. Model luar penting: indikator valid

f. Model dalam itu penting: ada pengaruh yang signifikan

g. PLS tidak menganggap bahwa data terdistribusi normal: menggunakan teknik resampling dengan metode Bootstrap

\section{Asumsi dalam PLS}

Asumsi dalam PLS hanya terkait dengan pemodelan persamaan struktural:

a. Hubungan antara variabel laten dalam model dalam adalah linier dan aditif

b. Model struktural bersifat rekursif.

\section{HASIL DAN PEMBAHASAN}

Data yang dikumpulkan dari kantor energi dan sumber daya di Palembang untuk melakukan kunjungan ke situs di tempat pengolahan bahan mineral, terutama batubara. Tindakan penelitian yang telah dilakukan oleh tim untuk memproses data dengan tujuan meningkatkan efektivitas operasi dan pengawasan unit dengan mengoperasikan sistem operasi untuk memperoleh tingkat pemanfaatan unit yang optimal dan pencapaian produksi. Beberapa informasi dan data yang telah diperoleh dari penelitian ini telah disebutkan pada awal laporan penelitian ini, yaitu kegiatan unit dan jam kerja, rencana dan 
realisasi volume produksi, jam kerja unit, breakdown ke unit, pencapaian hasil, produktivitas dan perencanaan lebih lanjut.

Penelitian ini terdiri dari 3 variabel laten yaitu, manajemen, pengeluaran, dan output. Variabel laten manajemen terdiri dari indikator jumlah jam meter, jumlah bahan baku, jumlah produksi, dan jumlah pekerja. Variabel laten pengeluaran terdiri dari indikator biaya perawatan, biaya bensin, dan biaya alat berat. Variabel laten output terdiri dari indikator output domestik dan output ekspor. Dalam penelitian ini, akan terlihat pengaruh manajemen dan biaya pengeluaran terhadap output. Analisis awal yang akan digunakan adalah SEM menggunakan estimasi Partial Least Square (PLS). Perangkat lunak yang digunakan adalah Smart PLS versi 2.0 M3 dan para peneliti telah diberi lisensi oleh smartpls.com. Data dalam penelitian ini akan disingkat nama-nama indikator sehingga ketika mereka muncul di perangkat lunak Smart PLS, nama indikator tidak terlihat terlalu panjang. Singkatannya adalah sebagai berikut:

UTAMA: Biaya Pemeliharaan

BEN: Biaya Bensin

AB: Biaya Peralatan

HM: Jumlah Meter Jam

JBB: Jumlah Bahan Baku

JP: Total Produksi

TK: Jumlah Pekerjaan Mati

DOM: Output Domestik

EKS: Output Ekspor

Hasil analisis SEM-PLS setelah diproses melalui perangkat lunak Smart PLS adalah sebagai berikut:

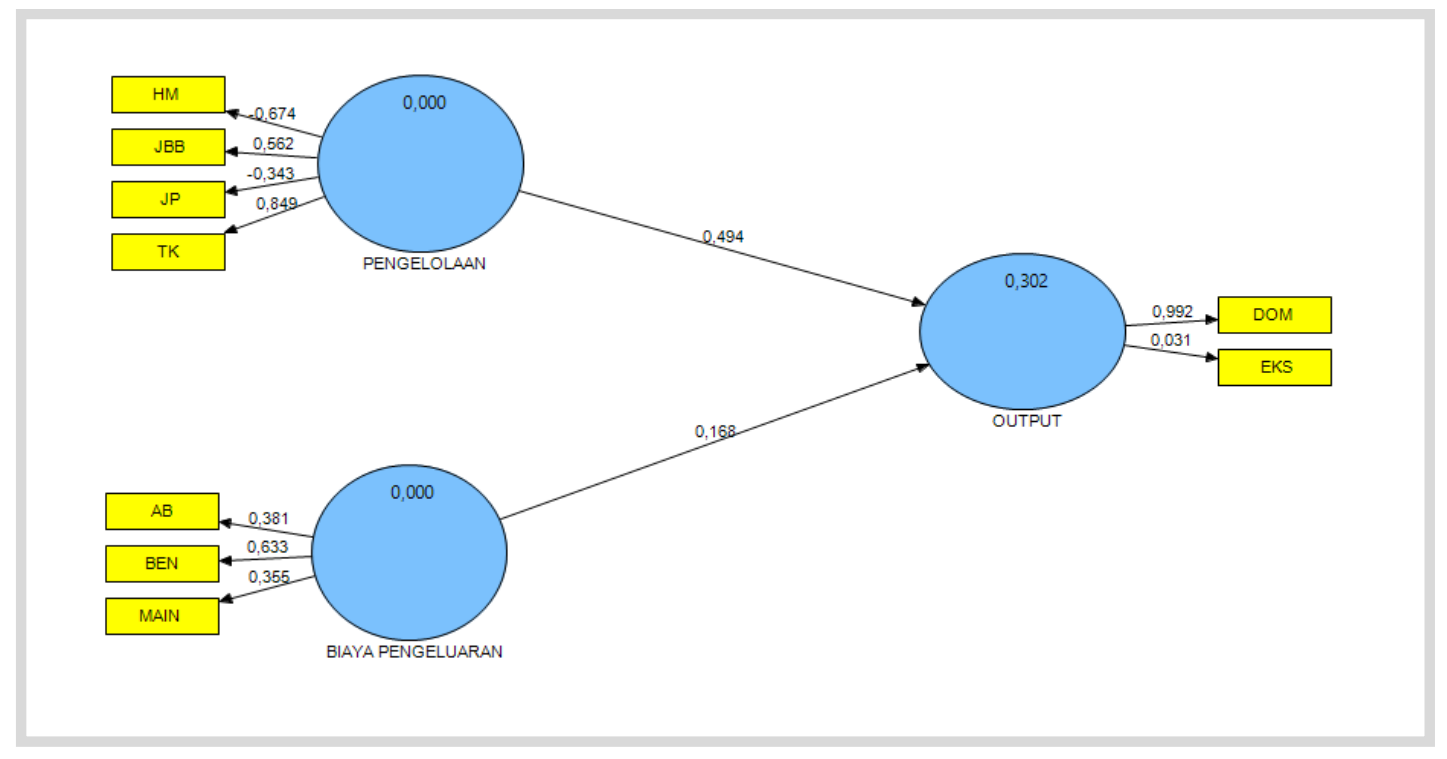

Gambar 5. Evaluasi hasil hubungan antara manajemen, pengeluaran dan output

Pada Gambar 5 dapat dilihat nilai loading factor dalam model pengukuran dan nilai koefisien jalur pada model struktural. Tetapi sebelum menarik kesimpulan dari analisis 
SEM-PLS, harus dievaluasi pada model apakah memenuhi persyaratan atau tidak. Evaluasi akan dibahas dalam diskusi berikut.

Evaluasi Model Luar, Uji Validitas Konvergen

Tabel 1. The loading factors of each indicator

\begin{tabular}{|l|}
\hline LATEN VARIABLES INDICATORS LOADING FACTORS \\
\hline EXPENSES FEES Cost of Heavy Equipment 0.381300 \\
\hline EXPENSES FOR Gasoline Costs 0.632937 \\
\hline EXPENSES FEES Maintenance Costs 0.355077 \\
\hline OUTPUT Domestic Output 0.991561 \\
\hline OUTPUT Export Output 0.030794 \\
\hline MANAGEMENT Total Hour Meter $-0,673739$ \\
\hline MANAGEMENT Total Raw Material 0.562205 \\
\hline MANAGEMENT Total Production -0,342656 \\
\hline MANAGEMENT Total Workforce of 0.848892 \\
\hline
\end{tabular}

Dari Tabel 1 dapat dilihat bahwa ada beberapa indikator yang memuat faktor lebih kecil dari 0.5, yaitu, indikator biaya alat berat dan biaya pemeliharaan pada variabel pengeluaran, indikator output ekspor pada variabel output, indikator jumlah jam meter dan jumlah produksi dalam variabel manajemen. Ini menunjukkan bahwa indikator tidak konvergen adalah valid.

Tabel 2. Communality and AVE

\begin{tabular}{|l|l|l|l|}
\hline VARIABEL & LATEN & COMMUNALITY & AVE \\
\hline EXPENSES & FEES & 0.224027 & 0.224026 \\
\hline OUTPUT & 0.492071 & 0.492070 & \\
\hline MANAGEMENT & 0.402007 & 0.402007 & \\
\hline
\end{tabular}

Dalam Tabel 2 dapat dilihat bahwa tidak ada nilai-nilai komunalitas dan AVE pada setiap variabel laten lebih besar dari 0,5. ini menunjukkan bahwa indikator yang menyusun variabel laten ini tidak konvergen adalah valid.

Sebenarnya masih ada beberapa evaluasi lebih lanjut, yaitu, uji validitas diskriminan, uji reliabilitas, evaluasi model formatif, dan evaluasi model struktural, tetapi evaluasi tidak akan dilanjutkan karena indikator yang terbukti konvergen tidak valid. Dengan kata lain, meskipun evaluasi selanjutnya menghasilkan nilai yang memenuhi kriteria, menggambarkan kesimpulan dari model tidak dapat dilakukan karena ada tes yang tidak terpenuhi, yaitu beberapa indikator yang konvergennya tidak valid.

Analisis SEM-PLS dalam penelitian ini tidak dapat dilanjutkan karena uji validitas konvergen tidak memenuhi kriteria. Mungkin salah satu alasannya adalah bahwa data yang diperoleh adalah data sekunder yang indikatornya sudah memiliki alat pengukur sendiri dan tentu saja menghasilkan unit yang berbeda. Misalnya, indikator jumlah bahan baku yaitu unit adalah ton dan indikator adalah jumlah pekerja yang unitnya adalah orang. 
Mungkin saja jika kombinasi kedua indikator dalam pengukuran manajemen akan menghasilkan kombinasi yang sangat lemah.

Solusinya adalah bahwa indikator dalam penelitian ini tidak lagi dianggap sebagai indikator tetapi dianggap sebagai variabel langsung yang saling mempengaruhi. Sehingga analisis selanjutnya yang akan diterapkan dalam penelitian ini adalah analisis regresi dengan menggunakan estimasi partial least square (PLS Regression).

Analisis selanjutnya adalah Regresi PLS atau analisis regresi menggunakan estimasi partial least square. Estimasi parameter regresi dengan PLS tidak memerlukan berbagai asumsi sehingga tidak perlu untuk uji normalitas, uji homogenitas, uji multikolinieritas, dan uji autokorelasi karena estimasi PLS tidak menggunakan fungsi distribusi normal dalam penilaian.

Hipotesisnya adalah sebagai berikut:

- H0: Biaya perawatan tidak mempengaruhi output domestik $\mathrm{H} 1$ : Biaya perawatan memengaruhi output domestik

- H0: Biaya bensin tidak mempengaruhi output domestik H1: Biaya bensin mempengaruhi output domestik

- H0: Biaya alat berat tidak berpengaruh pada output domestik H1: Biaya alat berat mempengaruhi output domestik

- H0: Jumlah jam meter tidak berpengaruh pada output domestik H1: Jumlah jam meter mempengaruhi output domestik

- H0: Jumlah bahan baku tidak berpengaruh pada output domestik H1: Jumlah bahan baku mempengaruhi output domestik

- H0: Total produksi tidak mempengaruhi output domestik H1: Jumlah produksi mempengaruhi output domestik

- H0: Jumlah pekerja tidak mempengaruhi output domestik H1: Jumlah pekerja mempengaruhi output domestik

- H0: Biaya perawatan tidak mempengaruhi output ekspor H1: Biaya perawatan mempengaruhi hasil ekspor

- H0: Biaya bensin tidak berpengaruh pada output ekspor $\mathrm{H} 1$ : Biaya bensin mempengaruhi hasil ekspor

- H0: Biaya alat berat tidak berpengaruh pada output ekspor H1: Biaya alat berat mempengaruhi hasil ekspor

- H0: Jumlah jam meter tidak berpengaruh pada output ekspor H1: Jumlah jam meter berpengaruh pada output ekspor

- H0: Jumlah bahan baku tidak berpengaruh pada output ekspor H1: Jumlah bahan baku mempengaruhi hasil ekspor

- H0: Jumlah produksi tidak berpengaruh pada output ekspor H1: Jumlah produksi mempengaruhi output ekspor

- H0: Jumlah pekerja tidak berpengaruh pada output ekspor H1: Jumlah pekerja mempengaruhi hasil ekspor

$\mathrm{T}$ test (bootstrap) 


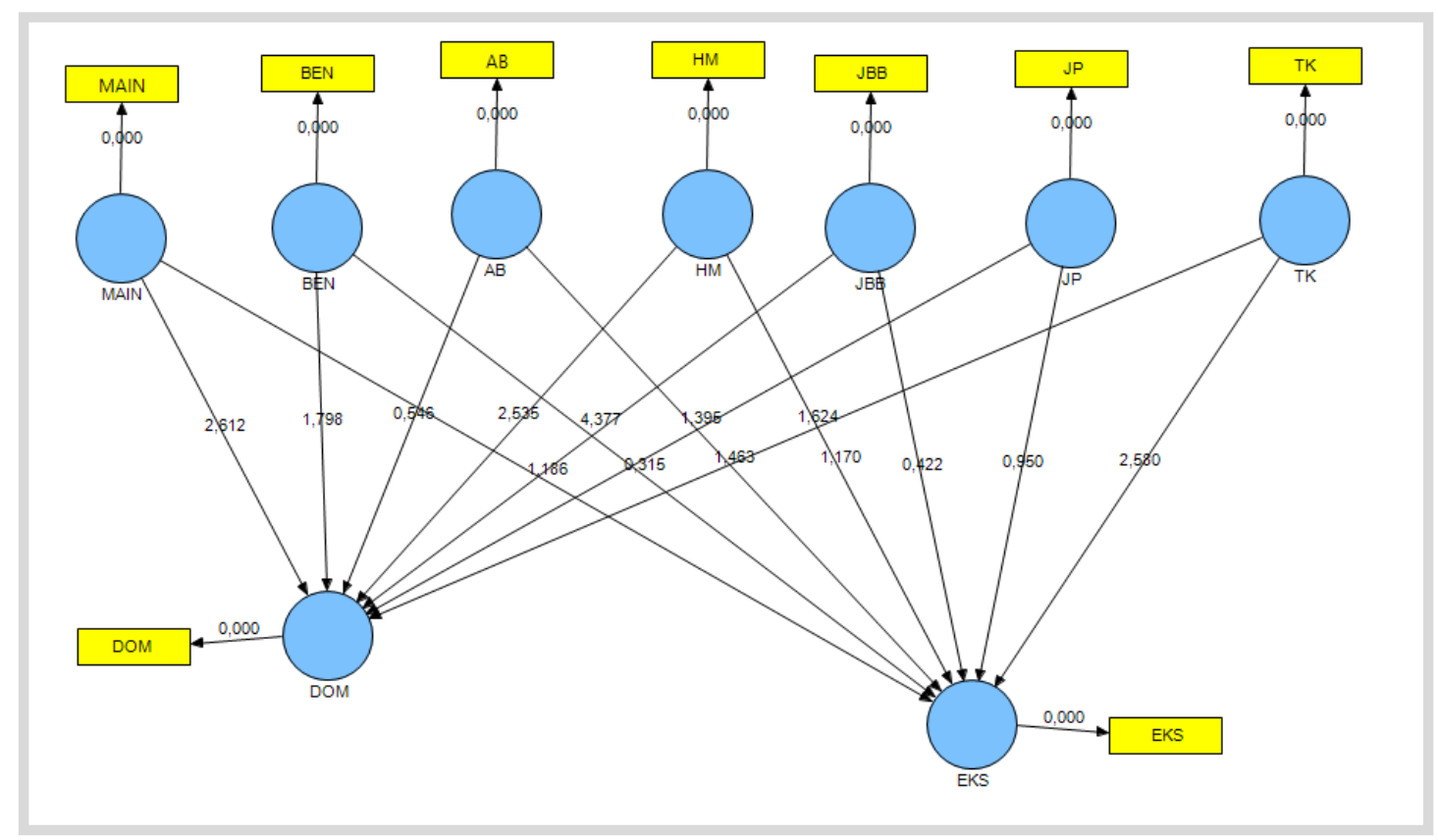

Gambar 6. Tes T (bootstrap)

Pada Gambar 6 dapat dilihat nilai-nilai hitung t untuk masing-masing variabel bebas terhadap variabel terikat. Ini bertujuan untuk menjawab hipotesis yang telah disiapkan. Kriteria penolakan untuk $\mathrm{H} 0$ atau dengan kata lain berpengaruh jika nilai t-hitung> 1,96. Untuk membuat lebih mudah dalam melihat nilai-t, nilai pada Gambar 6 dipindahkan ke Tabel 3.

Tabel 3. T-values

\begin{tabular}{|l|}
\hline EFFECT t-count \\
\hline Maintenance Costs ----> Domestic Output 2,612 \\
\hline Gasoline Cost ----> Domestic Output 1,798 \\
\hline Machine Cost ----> Domestic Output 0.546 \\
\hline Number of Hour Meters ----> Domestic Output 2,535 \\
\hline Total Raw Materials ----> Domestic Output 4,377 \\
\hline Total Production ----> Domestic Output 1,396 \\
\hline Amount of Work ----> Domestic Output 1,624 \\
\hline Maintenance Costs ----> Export Output 1,186 \\
\hline Gasoline Cost ----> Export Output 0,315 \\
\hline Cost of Equipment -> Export Output 1,463 \\
\hline Hour Meter ----> Export Output 1,170 \\
\hline Total Raw Materials ----> Export Output 0.422 \\
\hline Total Production ----> Export Output 0,950 \\
\hline Amount of Work ----> Export Output 2,580 \\
\hline
\end{tabular}

Dari Tabel 3 dapat dilihat bahwa variabel yang memiliki pengaruh signifikan terhadap output domestik adalah variabel biaya perawatan, jumlah bahan baku, dan jumlah jam meter karena masing-masing memiliki nilai t lebih besar dari 1,96. Sedangkan variabel yang berpengaruh signifikan terhadap output ekspor hanya jumlah pekerja. 


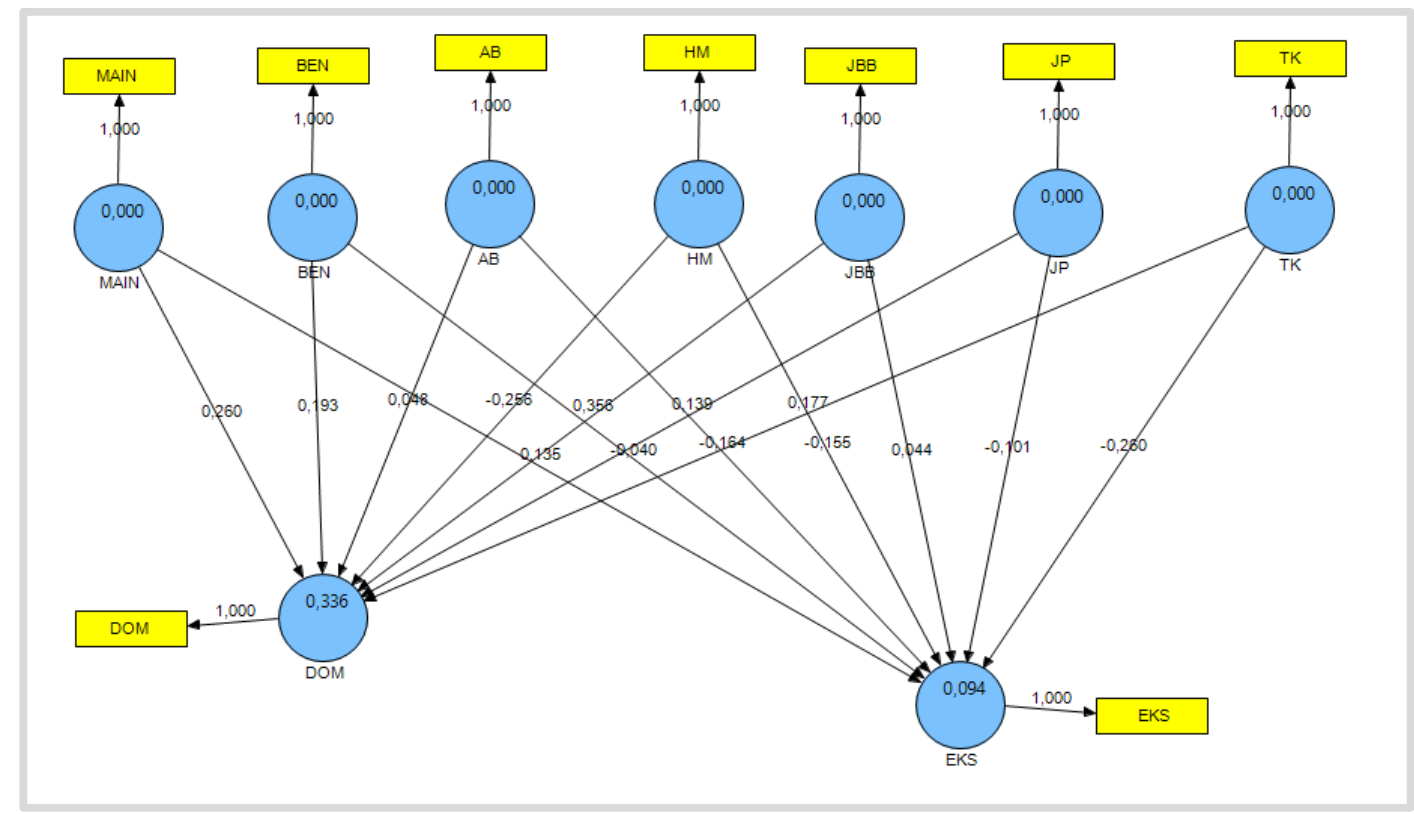

Gambar 7. Koefisien Regresi

Interpretasi koefisien regresi hanya akan fokus pada variabel independen yang memiliki pengaruh signifikan pada variabel dependen seperti yang ditunjukkan Gambar 7 karena jika tidak memiliki efek signifikan, koefisien regresi menjadi tidak berarti.

\section{KESIMPULAN DAN REKOMENDASI}

Dari hasil pengolahan data yang digunakan adalah regresi langsung yang juga merupakan bagian dari metode SEM, dan dapat dinyatakan dengan hubungan yang ada di bawah ini.

1. Biaya Pemeliharaan ----> Output Domestik

Ketika biaya pemeliharaan meningkat satu unit, output domestik akan meningkat sebesar 0,26 juta ton. Dari pemeliharaan data (Perawatan dilakukan untuk menjaga alat berat bekerja dalam sehari). Biaya perawatan dalam hal ini adalah ketika memperbaiki alat berat yang rusak, mekanik melakukan perbaikan baik di dalam mesin atau kerusakan pada satu bagian dari alat.

2. Jumlah Meter Jam ----> Output Domestik

Ketika jumlah jam meter naik satu unit, output domestik akan berkurang 0,256 juta ton. Untuk menjaga stabilitas alat berat, perlu untuk melihat jumlah jam meter di mana ketika alat berat tidak melakukan kegiatan tidak akan memiliki efek atau dampak besar pada output (domestik). Sebaliknya, jika semua alat berat bekerja dan tidak ada keseimbangan jumlah produksi dengan departemen distribusi penjualan, maka ketika jumlah produksi sangat tinggi (karena alat berat bekerja untuk melanjutkan produksi), maka bagian distribusi produksi tidak akan punya cukup waktu untuk melakukan penjualan di bagian domestik. 


\section{Jumlah Bahan Baku ----> Output Domestik}

Ketika jumlah bahan baku naik satu juta ton, produksi dalam negeri akan meningkat 0,358 juta ton. Jumlah bahan baku yang akan digunakan dalam produksi akan terkait langsung dengan jumlah distribusi produksi yang dijual di output, sehingga tingkat produksi seimbang dengan jumlah output yang digunakan dalam output (domestik).

4. Jumlah Pekerjaan ----> Output Ekspor

Ketika jumlah pekerja meningkat sebesar 1 orang, output ekspor akan berkurang 0,260 juta ton. Jumlah pekerja juga akan mempengaruhi jumlah output di sektor ekspor karena semakin banyak pekerja akan memberikan kontribusi besar untuk kegiatan produksi ke departemen distribusi.

Direkomendasikan untuk melakukan penelitian dalam jumlah alat berat yang akan digunakan dan berapa banyak alat berat lain untuk mendukung kelanjutan kegiatan pengolahan mineral. Direkomendasikan juga untuk penelitian lebih lanjut dengan menambahkan variabel lain yang dapat mempengaruhi tingkat produksi untuk digunakan di dalam negeri.

\section{REFERENSI}

Bochori, Asyik, M., \& Jhon, F. W. (2016). Model Transportasi Pengangkutan Batubara Ke Lokasi Dumping Dengan Metode Sudut Barat Laut Dan Metode Biaya Terendah Pada PT. Bukit Asam (PERSERO), Tbk. Jurnal Pertambangan(Vol 1, No 1 (2016)). Retrieved from https://ejournal.unsri.ac.id/index.php/mining/article/view/3814

Dubiński, J. (2013). Sustainable Development of Mining Mineral Resources. Journal of Sustainable Mining, 12(1), 1-6. doi:https://doi.org/10.7424/jsm130102

Febrianto, A., Nursanto, E., \& Poetranto, D. (2016). Kajian Teknis Produksi Alat Gali-Muat Dan Alat Angkut Pada Pengupasan Overburden Di Tambang Batubara Pt. Rian Pratama Mandiri Kabupaten Tanah Laut Provinsi Kalimantan Selatan. Jurnal Teknologi Pertambangan(Vol 1, No 2 (2016)). Retrieved from http://jurnal.upnyk.ac.id/index.php/itp/article/view/1498

Heinrich, L., Koschinsky, A., Markus, T., \& Singh, P. (2019). Quantifying the fuel consumption, greenhouse gas emissions and air pollution of a potential commercial manganese nodule mining operation. Marine Policy. doi:10.1016/j.marpol.2019.103678

Hermawan, K. S., Kresno, K., \& Titisariwati, I. (2016). Kajian Teknis Produksi Alat Muat Dan Angkut Pada Kegiatan Pengupasan Tanah Penutup Di Central Busang Blok 5d Pt Tanito Harum Tenggarong Kalimantan Timur. Jurnal Teknologi Pertambangan(Vol 2, No 1 (2016)). Retrieved from http://jurnal.upnyk.ac.id/index.php/jtp/article/view/1667

Janoszek, T. (2013). Exergy Analysis of the Coal Gasification Process in Ex-Situ Conditions. Journal of Sustainable Mining, 12(3), 32-37. doi:https://doi.org/10.7424/jsm130304

Kudełko, J., Wanielista, K., \& Wirth, H. (2013). Economic Evaluation of Mineral Extraction Projects from Fields of Exploitation During Operational Periods. Journal of Sustainable Mining, 12(1), 41-45. doi:https://doi.org/10.7424/jsm130108

Leeson, D., Mac Dowell, N., Shah, N., Petit, C., \& Fennell, P. S. (2017). A Techno-economic analysis and systematic review of carbon capture and storage (CCS) applied to the iron and steel, cement, oil refining and pulp and paper industries, as well as other high purity sources. International Journal of Greenhouse Gas Control, 61, 71-84. doi:https://doi.org/10.1016/j.ijggc.2017.03.020

Majer, M. (2013). The Practice of Mining Companies in Building Relationships with Local Communities in the Context of CSR Formula. Journal of Sustainable Mining, 12(3), 38-47. doi:https://doi.org/10.7424/jsm130305 
Munawer, M. E. (2018). Human health and environmental impacts of coal combustion and post-combustion wastes. Journal of Sustainable Mining, 17(2), 87-96. doi:https://doi.org/10.1016/j.jsm.2017.12.007

Smoliński, A. (2019). Journal of Sustainable Mining - The continuous quality improvement strategy. Journal of Sustainable Mining, 18(2), 85. doi:https://doi.org/10.1016/j.jsm.2019.02.004

Wijaya, A. A., Hartono, H., Widodo, P., \& B, W. S. (2015). Rancangan Teknis Penambangan Batubara Di Kecamatan Sebuku, Kabupaten Nunukan Utara Provinsi Kalimantan Utara. Jurnal Teknologi $\begin{array}{lllllll}\text { Pertambangan } & (\text { Vol } & 1, & \text { No } & 1 & \text { (2015)). } & \text { Retrieved from }\end{array}$ http://jurnal.upnyk.ac.id/index.php/jtp/article/view/1475

Wirth, H., Kulczycka, J., Hausner, J., \& Koński, M. (2016). Corporate Social Responsibility: Communication about social and environmental disclosure by large and small copper mining companies. Resources Policy, 49, 53-60. doi:10.1016/j.resourpol.2016.04.007 